\title{
Mathematics Competence and International Mathematics Testing: Croatian Starting Point
}

\author{
Mladen Domazet \\ Institute for Social Research - Zagreb (Centre for Educational Research and \\ Development), Croatia \\ e-mail:domazet@idi.hr
}

\section{Branislava Baranović}

Institute for Social Research - Zagreb (Centre for Educational Research and Development), Croatia

e-mail:baranov@idi.gr

\section{Jelena Matić}

Institute for Social Research - Zagreb (Centre for Educational Research and Development), Croatia

e-mail: matic@idi.hr

\begin{abstract}
The article presents a review of the competence-framed concept of compulsory mathematics education and appropriate instruction methods, in light of the international influences on Croatia through comparative ranking in PISA mathematical literacy. We begin by reviewing the conceptual constructs behind social influences on the supra-national development of the literacy/competence concept in mathematics education and assessment, and briefly examine its components and instructional contributions. Within this context we proceed to map past and current, and extrapolate future, changes in the conceptualisation of school mathematics and mathematics teaching in Croatian compulsory education, including recent empirical findings on mathematics instruction in Croatian primary schools. The aim is to examine social and (comparative) political influences on subject-matter and teaching of 'hard' school subjects such as mathematics, chart Croatia's current position according to international assessment and instructional trends, and recommend possible steps in immediate development of educational policy.
\end{abstract}

Key words: PISA testing, competence, literacy, mathematics, instruction, problem-based learning, compulsory education in Croatia. 


\section{Mathematical Knowledge, Mathematical Competence and PISA: What does Society Want from Compulsory Mathematics Education?}

When comparing the conceptual and social development of the aims of mathematics instruction to the performance in international assessment such as OECD's PISA, the crucial leverage is provided by the teachers' understanding of the aims of mathematics instruction and their access to and choice of practices to achieve it. As the aims of mathematical education change under international and social exertion, can the classroom practices, and teachers primarily responsible for it, follow? In the mid1990s international comparisons of educational systems and content began taking shape (Bishop, Clements, Keitel, Kilpatrick and La-borde, 1996.), including mathematics education. In fact, 'hard subjects' such as mathematics and science education, provided a more stable ground for comparison than the more context dependent liberal arts education (Domazet, 2006.). Thus, PISA international assessment assumes that mathematical knowledge and skills are not culture-bound and thus are fully internationally comparative.

In a comparative mathematics education volume from 1996. M. Niss (as cited in Hoogland and Jablonka, 2003.:1) states that traditional goals of mathematics education had been, by then, considerably broadened to include the "essential aspects of numeracy and "mathematics literacy" in society" (Hoogland and Jablonka, 2003.:1). Despite that statement 'literacy' does not as yet feature strongly in the actual content of the review. By 2003., and the next edition of the same review, the situation changes drastically. This is also the time when the international PISA assessment, which strongly features the 'mathematical literacy' context, begins to permeate educational development thinking in increasing number of countries. The PISA theoretical framework has many similarities with the theoretical perspective adopted for mathematics education called realistic mathematics education, which is itself rooted in $\mathrm{H}$. Freudental's ideas about mathematics teaching (Freudenthal, 1973.).

It is important to mention here that realistic mathematics education (RME) is, as a teaching and learning theory, substantially determined by Freudenthal's view of mathematics as a human activity connected to reality, close to children and relevant to society (Heuvel-Panhuizen, 2003.:10). Accordingly, in addition to the use of contexts in mathematics teaching and learning, RME attached significant importance to mathematics teaching as a process in which students develop and apply mathematical concepts and tools in a realistic problem context. As opposed to the traditional mathematics education, such an approach presented a shift towards modernisation of mathematics education and its current developments. Subsequently, different social influences on the broadened definition of goals of mathematics education can be detected, from developing human capital to achieving environmental awareness or social change (Jablonka, 2003.). Mathematical education was no longer just about transferring the canon of 'mathematical knowledge' to the uninitiated youth, but about satisfying broader social goals in that. And the national framework curricula and international assessment were to reflect that aim. 
Perhaps this trend is globally today most evident in the OECD/PISA approach (Organisation for Economic Co-operation and Development [OECD], 1999.) which includes mathematics education as one of the instruments of development of human capital. Mathematics was not just some abstract body of knowledge, but contained skills and a way of thinking to be applied in numerous real-life situations, professional tasks and global cooperation. Through broadening to 'literacy' applicable in wider contexts than a classroom, mathematics education was to become more causally relevant to raising living standards and intensification of economic activity (development of human capital, Jablonka, 2003.).

When comparing the 'mathematical literacy' definitions of the contemporary international PISA assessment and the more traditional expectations of mathematics education that Croatian teachers were trained in and work with, a gradual change from abstract training in understanding of the world's deterministic regularities to participation in a numerical-analytical society is observed. This is a reflection of the global trend of linking mathematics education with real-life contexts, and expression of societal pressures extraneous to specific subject concept on the definition of educational outcomes. Because existence of such pressures cannot be ignored, they are relevant to the review of conceptual construction of a specific subject (in this case the 'hard' subject of mathematics, cf. Domazet, 2006.) and its teaching practices, without being used as an overall assessment of an intrinsic quality of mathematics education in Croatia.

The most senior practicing teachers (just under 40\% of overall lower-secondary teacher population according to 2003. research, Baranović, 2006.) would have been initially instructed that "The aim of primary mathematics education is to introduce the students to quantitative understanding of the world, to identification of mathematical structures that are used to describe the phenomena and the regularities in social and natural sciences, and are applied in everyday life." (Furlan, Kaučić, Muhvić, Podgorski, and Zadrović, 1974.:72) This definition is immediately followed by a list of instructional tasks in mathematics which contains various forms of mathematical knowledge and understanding but no specifics of their application in life other than general rationality and orderly precision. At the outset of Croatian transition (1991.) no significant content change is reported in mathematics instruction (Jakopović, 1991.), and average age of practicing maths teachers in Croatia makes this their primary training definition (Baranović, 2006.). Some instructional changes are advised with claims that teacher-centred lecture-style instruction cannot ensure adequate development of youths as it 'passivises' the young person and hinders the personality development. Although mathematical instruction is expected to prepare students for employment and scientific and technological development of the state, application of knowledge in students' everyday life is listed in the last place.

In a first revision of the educational content in the transitional period (Ministry of Education and Sport of Republic of Croatia, 1999.) practical applicability of mathematical knowledge is abandoned altogether and the overall aims of mathematics are listed purely in terms of knowledge appropriation and its application in further learning and other natural and social sciences. Again mathematics is tasked with 
developing rational thinking, orderliness and precision of expression. Although, of course, all of those can be applied in everyday life, there is no explicit mention of the real-life situation or specific professional tasks. Subsequent revision in 2006. (with PISA present on the global stage) lists the general goals of education as development of individual personalities and overall knowledge society, but no particular application of knowledge is listed (Ministry of Science, Education and Sport of Republic of Croatia, 2006.). In mathematics instruction itself, enabling students to join various professions, economy, use contemporary technology and become members of contemporary society is cited, but the main goal of mathematics education is appropriation of foundational mathematical knowledge, development of basic mathematical literacy and ability to solve mathematical problems. Application of mathematical knowledge in everyday life is now listed higher up in instructional tasks, right after skills in mathematical expression and numerical literacy.

Finally, the most recent reform initiated in 2011. and ongoing, justifies compulsory mathematical education with the need to equip students to successfully participate in the society reliant on information and technology (Ministry of Science, Education and Sports of Republic of Croatia [MZOS], 2011.). Mathematical instruction is now repeatedly explicitly connected to its everyday and lifelong learning application in various forms (numeracy, spatial cognition etc.). The curriculum framework document explicitly states that through mathematical instruction "students will realise the importance of mathematics in their daily lives, gain insight into the historical development of the discipline, and come to understand its role and importance in the society of the past, present, and future. [...]They will gain exposure to mathematical problems found in real, everyday situations, thus linking the discipline with their everyday lives..." (MZOS, 2011.:80). Among the explicit goals of mathematical instruction, appropriation of basic mathematical knowledge and skills is immediately followed by the application of mathematical principles "in various contexts, including professional life" (MZOS, 2011.:80).

The PISA assessment on the other hand, tests for literacy defined as "an individual's capacity to identify, to understand the role that mathematics plays in the world, to make well founded judgments and to use and engage in mathematics in ways that meet the needs of that individual's life as a constructive, concerned and reflective citizen" (Organisation for Economic Co-operation and Development [OECD], 2003.: 24). ${ }^{1}$ The new concept of mathematics as mathematical literacy is of special importance for Croatia which has recently joined the PISA assessment and introduced changes of the mathematics curriculum as a part of the broader national curriculum reform (2011. reform mentioned above). Joining the assessment subjects the whole of Croatian compulsory mathematics education complex (curriculum-teachers-students-schooling processes) to rough-and-ready comparisons on global scale, which

$\mathbf{1}$ Though there are definitions of mathematical literacy assessed in PISA prior to and following the given 2003. definition, this is the one most closely related to the discussions in other sources cited in this text, as well as the one used at the outset of the 2003.-2009. period for which some comparative results are presented below. 
are more often than not one-dimensional in terms of ranking of means of assessment performance.

As such they ignore both the greater breadth of aims of school mathematics education than sole achievement of literacy in mathematics requires, and the variations in conceptual construction of mathematics education between Croatian contemporary textbooks and curricula on one side, and PISA educational outcomes definition on the other. Moreover, the international assessment rationale itself assumes that different curricula affects across countries are entirely unproblematic and comparable by simply choosing to adopt the trans-curricular character by fiat (Keitel and Kilpatrick, 1999.). Actual assessment of individual curriculum and instruction complex's performance must be aligned with explicit goals of the curriculum as they are prescribed to teachers (cf. Schoenfeld, 2002.). Thus, for example Glasnović-Gracin empirically illustrates the differences between goals of Croatian mathematics education as defined in in-use textbooks and curricula and PISA competences definition (Glasnović Gracin, 2012.). Furthermore, there are empirical demonstrations of how these discrepancies between international assessment programmes (such as PISA) and different national mathematics education complexes vary between countries, making the testing items more or less applicable to what the students were actually prepared for through education (Schmidt, Wang and McKnight, 2005., Schoenfeld 2002.; cf. also Mešić 2012. for related case of TIMSS international assessment).

Summarily put, what is important for our purposes here is that PISA should not be used to indicate the overall quality of particular national compulsory mathematics education, but its comparative output against a well-defined set of criteria, whilst noting the general influence such international assessment (and subsequent rankings produced) has on the curricula and instruction within countries (see below). In that light recent research findings on the state of the math education ${ }^{2}$ indicate (Baranovic and Štibrić, 2011.) that the Croatian teachers have notionally adopted the requirement of applicability of mathematical knowledge, but still perceive the operational components of this requirement in a traditional way.

Namely, when ranking the importance of students' learning outcomes ${ }^{3}$ mathematics teachers valued most highly application of mathematics in everyday life $56.0 \%$ of

2 The research we are referring to was carried out in 2010. using a random stratified representative sample of 625 math teachers (Grades 5-8) from elementary schools throughout Croatia which is $31 \%$ of the total number of math teachers working in elementary schools in Croatia during the data collection. The administered teachers' questionnaire covered the following dimensions of math education: teachers' mathematics-related beliefs, importance of students' learning outcomes that foster the development of mathematical literacy, students' activities during math lessons, usage of teaching materials and tools, teachers' estimates of the characteristics of the existing math curricula and teachers' perception of self-efficacy. The research results were presented at the ECER conference, held in Berlin in 2011. (Baranović and Štibrić, 2011.).

3 Out of 18 offered students' learning outcomes, the teachers were asked to choose 5 outcomes to which they attribute most attention. 
teachers' responses) and adoption of a positive attitude towards mathematics (55\% of responses) while most other learning outcomes, which are characteristic of PISA concept of mathematical literacy, were ranked very low: e.g. students' reasoning about mathematical concepts and processes (13\% of responses), critical thinking about math concepts and procedures (15\% of responses), mutual communication of ideas and results (18\% of responses) etc. At the same time, and as indicated by the operational goals of mathematics instruction above, the teachers attributed relatively significant attention to the specific learning outcomes which are typical of traditional approach to mathematics, e.g. students' hard and thorough work during math lessons (35.0\% of responses), students' confidence in solving standard mathematical tasks (31.5\% of responses), mastering the math syllabi (32\%), etc. (Baranović and Štibrić, 2011.).

Though aimed at the 'same animal' (Niss, 2003.b:215), different historical and present-day delineations of school mathematics instruction place different emphasis on the everyday social and professional context of the current students and future employees and citizens. Whereas Croatian 1970s and 1980s students were expected to be initiated into the quantitative understanding of the world, which would in part open up the riches of natural and social scientific description of it, the 2000s global citizens, trained in mathematical literacy, are much more focused on the judgements about the role of mathematics in occupational and social life. This further illustrates the difference in construction of the desired outcomes of compulsory mathematics education through time in Croatia and globally, which also bears on the straightforward assessment performance of the student population.

M. Niss (one of the participants of the PISA conceptual team) is explicit (Niss, 2003.b:216) about the role of mathematical literacy in maintenance of, and participation in, democratic social activities, something that mathematics as pure, fundamental science is decidedly outside of. And although maintenance and participation in the social order and societal operations will involve many mundane activities like checking someone else's sums, Niss is convinced of the deeper role that mathematical literacy plays in a society, a role that goes back some way to the "quantitative [and scientific] understanding of the world" (Furlan et al., 1974.:72). He says that it has a role to play in allowing individuals to come to grips with how mankind perceives the world, its natural, social, cultural and technological aspects. "[Mathematical literacy is an essential component] in liberating literacy and popular enlightenment" (Niss, 2003.b:217). Again, bearing in mind that PISA does not explicitly asses the mathematics curriculum, whose goals should be broader than the outcomes assessed by PISA programme (cf. Schmidt et al., 2005.), we note that training solely for literacy and 'applied knowledge' can miss out on the depth and comprehensive understanding of mathematics subject matter even when achieving high performance in assessment (Schoenfeld, 1988.).

There is a worry that 'mathematical literacy' is just 'easy mathematics', the 'mathematics for the un-mathematical'. From the perspective of the historical and social influences on the broadening of mathematical instruction and educational aims, it is worth heeding a statement from apartheid-conscious South Africa (Julie, 2006.) 
that 'mathematical literacy', even when perceived as 'easy mathematics', is democratically enabling for a broader population. Given the stated importance of mathematics in everyday life in contemporary society it is exclusive to limit the instruction and understanding to only those with 'mathematical potential'. Julie is adamant that mathematical literacy, whether we like it or not, is justified by globalisation, technological availability of access to knowledge and the "world-wide thrust for regular testing [...] through international comparative studies". Nonetheless, even as 'literacy', school mathematics can come in empowering or disabling forms, as a tool contributing to the participation in the spectrum of relevant global worldviews or as just a 21st century version of basic arithmetic (Julie, 2006.). And in South Africa the public can still remember how the latter 'lower form' of mathematics instruction was used as a tool of discrimination and domination.

For the purposes of this paper it is worth noting the liberty to switch between the mathematical literacy and mathematical competence. Though there might be entire volumes dedicated to fishing out the fine details of the difference, we shall contend here with using both to describe the mathematical ability that can be and is applied outside the strict mathematical factual knowledge reproduction tests. So Hoogland and Jablonka (2003.) say that various definitions of mathematical literacy relate to an individual's capacity to understand mathematical aspects of everyday situations and make judgements about them based on the mathematics learnt at school. As we have seen above, PISA includes in the definition of mathematical literacy engagement in mathematics and forming of judgements of the roles mathematics plays in current and future lives of the students. Likewise, a more socio-politically motivated concept of competence (which in several of its European iterations explicitly includes mathematical competence) is based on the DeSeCo attempts to define 'key competences useful for a successful life for individuals and a well-functioning society', and progresses towards, for example, "the ability to apply learning outcomes adequately in a defined context (education, work, personal or professional development)" (Office for Official Publications of the European Communities [CEDEFOP], 2008.).

Moreover, the DeSeCo elaborates that 'competence is not limited to cognitive elements; it also encompasses functional aspects (involving technical skills) as well as interpersonal attributes (social or organisational skills), values and ethics, attitudes, emotions, and motivation (Rychen and Salganik, 2003.; CEDEFOP, 2008.). Indeed, Silver $(2003.27)$ refers to the historical foundation of the attempts at settling the definition of mathematical competence in the definitions of literacy, numeracy and expertise. Silver hints at mathematical competence potentially being a wider term than literacy, so as to include more of the academic or expert reasoning, whilst maintaining the applicability to everyday life requirements. For the purposes of the discussion of the innovations of teaching practices we can safely focus on the part of competence where it fully overlaps with literacy, the part in which mathematics instruction has to focus on something more than the initiation into the academic discipline. Silver himself will warrant this with stressing the importance of examining the application of mathematical knowledge in context of its everyday applicable use.

Niss, as one of the authors of the PISA definitions, bases the definition of mathematical competence on the supposedly more familiar notion of literacy in general (Niss, 
2003.a). Just as literacy involves the mastery of written and spoken language, a use of language, so mathematical competence consists of the ability to understand and use mathematics in a variety of mathematics-related contexts and situations in which mathematics plays a crucial role. This, of course, consists of the mastery over a lot of factual knowledge and domain-specific skills but cannot be reduced solely to those.

It is also important to note for our purposes here that there are attempts to define competence as an "attribute of participation in an activity system" (Gresalfi, Martin, Hand, and Greeno, 2009.; Engeström, 1993.; Greeno, 2006.; Lemke, 1990.). The purpose of introducing this dimension here is to highlight the social and cooperative aspects of mathematical competence. The point to be emphasised following Gresalfi et al. (2009.) is that what counts as "competent" becomes construed in individual classrooms, and can take a different appearance from one to another. Teachers and their own implicit definition of mathematics competence are most immediately responsible for such constructions.

With all those in mind, it is important that Croatian teachers today mostly realise the importance of teaching mathematics for its application in life, rather than initiation in the abstract discipline and worldview. However, beneath the surface expression of aim to 'apply mathematics in everyday life', they show low preference for some of the more specific learning outcomes that are characteristic of the new concept of mathematical competence. Following the introduction of those into the new National Framework Curriculum, they should be developed in greater detail in a way that teachers could implement in the lessons. But, as we shall see, curricular design is less than half of the story, as instructional practices and teachers general workload contribute to the attainment of students in standardised testing and their retention of knowledge for application in life.

\section{PISA: Testing for Life?}

Through the international assessment whose outcomes are most readily presented in the ranked form, the PISA definition of mathematical competence eventually influences, through pressures external to curriculum conception, the understanding of mathematics to be promulgated through the individual national curricula. That is if the participating countries want to enhance their international ranking performance, which most undoubtedly do as a matter of prestige. In fact, as Niss (2003.b:217) puts it, in order to comply with the PISA competition for rank "it becomes a crucial task to find and employ new ways to define and describe mathematics curricula that focus on mathematical competence rather than on facts and techniques". The other possible response is to highlight inadequacies in the PISA programme itself, which might incrementally contribute to its overall improvement, but will eventually reach the boundaries of 'aiming at the same animal' (cf. above) and reaping the benefits of contemporary mathematics education trends. What we are primarily interested here is the social phenomenon of influence of PISA on national instruction practices and curricula, whilst aware of the misalignment of Croatian compulsory mathematics education and PISA (cf. Glasnović Gracin, 2012. and above) and the general societal influence on competence construction (cf. Domazet, 2011.; Halász and Michel, 2011.). 
On the other hand, through Niss' own admission, (Niss, 2003.a:120) PISA definition of the desired mathematical literacy is influenced by the work on the Danish national programme of mathematical competence definition, in addition to the already mentioned RME development even further back (cf. Freudenthal, 1973. and above). What is interesting for our purposes is to briefly survey the competence concepts that were included in this definition, as well as the assessment practices based on those. According to Niss, competence concept in mathematics divides into two major groups of more specific competencies. The first group consists of capability in asking and answering questions in and with mathematics (Niss, 2003.a, p. 118): thinking mathematically, posing and solving mathematical problems, modelling mathematically, and reasoning mathematically. The second group represents capability to use mathematical language and tools: representing mathematical entities, handling mathematical symbols and formalisms, 'mathematics' communication, and making use of relevant and available aids and tools. These are the components closely shadowed even in the latest PISA assessment framework (Organisation for Economic Co-operation and Development [OECD], 2009.:106-7).

These have been developed in greater detail so as to try to address many perspectives on what mathematically competent person should emulate. There is no room here to enter into those, but what is more interesting is the ability to successfully test for the mastery of the complex competence defined in this way. This has to be achieved in a way to avoid the traditional and simple test of the initiation into the academic discipline of mathematics, but also to provide the teaching process with a realistic and reasonable outcome of instruction rather than some holistic property which some students have and others do not. If on the PISA definition, the competence requires the ability to 'identify, understand and engage in mathematics' and 'make judgements about the role of mathematics', what is the adequate instruction (and subsequent testing) to look like?

Niss understands, at least in part, the PISA definition as requiring the preparedness to act mathematically on the basis of knowledge and insight (Niss, 2003.a:119). And the test he envisages for that has to be founded on the range of the students' competences in relation to the mathematical activities they are or may be involved in as part of everyday life. Here he envisages the testing outcome to consist of the three dimensions product of which is the total competence level, as the spatial volume is the product of three spatial dimensions. The dimensions are the degree of coverage, the radius of action and the technical level of competence activation. What is traditionally mostly taught and tested for is the first dimension: the extent to which the students master different aspects of the school subject's cognitive content. But the complex notion such as PISA definition aims to test for requires the test to vary and assess for the spectrum of contexts in which the student can recognise the potential for and successfully draw on the different aspects of competence listed above. Finally, in the contemporary global context, the technical level calls for the assessment of the conceptual and technical complexity of the aids and tools the students can depend on to activate the application of different aspects of competence named above. 
A proviso immediately follows, that the fully adequate assessment of the possession of competence is more than a single test can hope to achieve. But when it tries to come even close to this, it has to provide as broad as possible a spectrum of activities in which the degree and range of competence possession can be demonstrated. In that respect, the PISA Assessment framework envisages several clusters of tasks in which combinations of component competences can be assessed for in different ways: the reproduction cluster, the connections cluster and the reflection cluster (OECD, 2009.). But the clusters also respect the hierarchy of complexity, with reflection being the most complex and the reproduction the simplest.

In this sense, the competence-based 'innovative' international framework shows clear connections to the foundations of mathematics teaching and testing: to reproduce the basic cognitive items and skills, to make independent connections and reason through broad reflection on the abstract knowledge in combination with the specificities of the given context. In that respect the PISA assessment presents a fine-tuning on the base of the traditional mathematics instruction ('introduction to quantitative understanding') that majority of Croatian teachers have been trained in. ${ }^{4}$ In other words, it is a question of reorienting and not rebuilding mathematics instruction. But the degree of reorienting required can be extensive, as will be discussed below.

Although national standardised testing takes increasing importance in quantifying and certifying educational outcomes in Croatia, the main outcome of competencebased education should still be a successful application of the competences developed to everyday life beyond schooling and assessment contexts. As has already been mentioned above, the research among Croatian teachers reflects as much: the highest ranking elements of mathematical competence as outcome are 'apply mathematics in everyday life' and 'adopt a positive attitude towards mathematics' showing the teachers are aware of the trends. However, some of the operational formulations of those outcomes, as derived from for example PISA-related definitions, enjoy a very low preference amongst teachers (as presented above). ${ }^{5}$

In a discussion of the effect of teachers on the international mathematics standardised assessment performance (comparisons of the performance of the East Asian and Western students in mathematics, such as Lapointe, Mead, and Askew, 1992.; Stevenson, Lummis, Lee, and Stigler, 1990.) teachers' own competence in mathematics and pedagogy was assumed to be a major factor in influencing student performance. However, repeated study by Leung and Kyungmee (2002.), comparing the East

${ }^{4}$ Only the most recent generation of the practicing mathematics teachers in Croatia will have undergone their initial teacher-training based on the more recent mathematical concept definitions (2006. and 2011.), whilst majority of the practicing teachers for their initial training relies on the 1974. conceptualization and its 1991. and 1999. derivatives.

5 Though PISA is not the only competence-based outcome construction, it is useful here for both its broad application and expansive examination, whilst providing an interesting expansive international comparison and paradigmatic societal influence on national education systems. 
Asian teachers from different regions (Shanghai, as presented in Ma, 1999., versus Hong Kong and Korea) found that it was the ability to specialise in mathematics teaching and the general workload that mostly contributed to the teachers' own competence in fundamental mathematics and their grasp of, and subsequent ability to freely manipulate, mathematical concepts. The advantage of Shanghai teachers, which registered both in their students' performance in standardises testing (cf. PISA performance overview below), but also in teachers' own test and concept manipulation performance stemmed from them teaching mathematics only and only in one grade in a certain year, whilst bearing a lighter teaching load, allowing them to devote their full attention to preparing the particular grade's (innovative, conceptually foundational) lessons.

The disadvantage of the other teachers assessed lead to their lower (though not insufficient) grasp of the fundamental mathematical concepts, but more importantly, to their reliance on traditional teacher-centred instruction that excludes the investigative navigating of students' own exploration or other instructional methods conducive to constructivist-based conception of mathematics learning and instruction. Leung and Kyungmee (2002.) admit that there was also some attitudinal justification for the teacher-centred procedural instruction, resting on the teachers' explicit beliefs that the problem-based learning is unsuitable for the early stages of schooling. That basic rules and procedures have to be 'drilled' first. However, when pressed to explain the success of the non-Shanghai East Asian students in the standardised testing, despite the limitations their teachers face, Leung and Kyungmee (2002.) claim that fundamental conceptual understanding is not a prerequisite of a successful practical application of knowledge. They are of the belief that successful blind task completion through repeated practice can of its own lead to conceptual understanding at a later stage.

Be that as it may, Leung and Kyungmee (2002.) concede that only within a well designed curriculum, such that concepts are introduced in a measured interlace with systematically varying exercises, can such a 'practice-makes-perfect' route to understanding and eventual competence-mastery be followed. This sees a division of labour in mathematics instruction where the task of the conceptual innovation in mathematics instruction is carried by the curriculum and textbook designers. The teachers are then only asked to competently follow the curricular recommendations. This seems to be similar to the Croatian practice, where little freedom in curricular design is left to the teachers, and their teaching practices (as is reported below) reflect the focus on teacher-centred instruction. Nonetheless, the international performance certified competence of the East Asian students can be attributed, at least partly, to the competence of their teachers.

Country performances on the mathematical literacy scales can be a contested issue, which becomes obvious from the change in the mode of presentation of the results in PISA reports 2003. to 2009. (where bare statistical differences are replaced with a more narrative interpretation of the individual results' importance). However, for the purposes of this text there is no need to enter into their detailed analysis, and it is useful to approximately focus on the mode of presentation applied in the la- 
test report (Organisation for Economic Co-operation and Development [OECD], 2010.:134) where grouping of countries is provided with respect to significance ${ }^{6}$ of difference in score. In that respect, and regarding the literature drawn on in this text (Leung and Kyungmee, 2002.), it is illustrative to compare the mean overall performance of Croatian students in 2006. and 2009. to that of students from selected East Asian economies and countries consistently exhibiting a top performance, and participating countries from the former shared Yugoslavian state (Montenegro, Slovenia and Serbia) where structural similarities in educational goals and teacher education may exist.

We note the limitations of the PISA testing in relation to Croatian curriculum, as well as the variations in the assessment programme itself as described by Glasnović Gracin (2012.), but are not after relying on PISA rankings here to expose the quality of the overall mathematics curriculum or instruction. Moreover, whilst a lot of ink has been shed over analyses of national PISA performance and many different overall ratings constructed, it is the simple overall rankings of the type mentioned here that present the paradigmatic case for the international ranking pressures on the construction of national educational outcomes. This text, on the other hand does not endeavour to enter into details of analyses of comprehensive reasons for individual countries' performance (which would go far beyond curriculum and instruction alone), but to describe a simple link between educational outcome definitions in Croatian documents through time and contemporary international pressures.

East Asian countries and economies exhibit consistent performance at the top of the scale in mathematical literacy, which has sparked research interest some of which is drawn on below. Croatia participated in PISA assessment in 2006. and 2009., where the latter performance results slide downwards on point scale. Although its students performed below OECD average Croatia remains on the scale above Serbia and Montenegro. Slovenia, which is the first former Yugoslavian country that joined the European Union ${ }^{7}$, shows performance above OECD average ${ }^{8}$, but not as high as the East Asian countries and economies.

6 "Significance' here refers to statistical significance as presented by the official OECD PISA publications (OECD, 2010.).

${ }^{7}$ Slovenia introduced reforms to primary education structure in the 1990s by extending general compulsory education to 9 years (with 6 years primary education) and outcome-oriented national curriculum.

8 In PISA 2003. results presentation there are significant differences presented including and excluding the Bonferroni adjustment. We have no need to enter into this level of detail of statistical presentation here, as we are concerned only with a rough overall trend. However, as the exact rankings of countries' performances can be a sensitive issue politically we refer all readers to official detailed presentations of performance in the official PISA results publications (available at http://www.oecd.org/pages/0,3417.en 32252351322357311111111 1,00. html). 
Moreover, Croatian students rate mathematics among the least interesting and most difficult school subjects. It requires a lot of their study time and effort, even though they show awareness of its importance in both present and future life. Very few of them are encouraged to learn more, and report being mainly passive recipients of knowledge in mathematics lessons. Mathematics was ranked second of least liked school subjects, mainly for being difficult and incomprehensible (Marušić, 2006.). As stated above, also no radical changes in content and its presentation were introduced in the Croatian context, and the mathematics instruction is still primarily teacher-centred. Although mean ranking in international assessment programmes should not be the primary and only goal of mathematics instruction, given the complex intersection of students' attitudes to the subject, teaching practices and curricular aims it is worth exploring the link between curriculum and instruction, and acquisition of competence as tested by PISA (bearing in mind all its limitations and failures, as stated above).

\section{Teaching for Competence}

Not only is the development of competence a recently trendy expressed goal of schooling, it is also a conventional human need for those earnestly engaged in a learning process. It includes understanding when, where and how to achieve certain outcomes, and feeling efficacious in performing the actions leading to them. In this way the notion of competence is closely tied to the theories of motivation for studying mathematics, which in turn is closely connected to the way that the content is presented to the students. To support the acquisition of competence, rather than mastery over set tasks, communication about mathematics between teachers and students should be significantly altered from that used in traditional classrooms (Lampert, 1991.), the instruction that provides feedback, over and above the evaluation of testing success, should be conducted, and methods which focus on interactive, collaborative, and investigative teaching should be employed (Sriraman and English, 2010.). Turner et al. (1998.) show that such practices are related to increased intrinsic motivation to learn. Moreover, to make students themselves aware of the process of development of competence as part of motivation for learning, teachers need to provide space for students to reflect on what they do and do not understand, including explication of reasoning behind reaching certain correct and incorrect answers. This in turn leads to increased conceptual thinking which provides a firmer foundation for the overall competence in mathematics beyond the set school tasks (Kazemi and Stipek, 2001.). Facilitating students' cognitive restructuring and conceptual reorganizations that precede the school mathematics competence development is what constructivists see as one of the teachers' core responsibilities (Cobb, 1988.).

Qualitative study by Wilson, Cooney and Stinson (2005.) examined mathematics teachers' experiences and attitudes concerning how teaching for understanding should be designed. The interviewees offered some insights on their own and students' prerequisites for competence development. Former refers to teachers' need for de- 
veloping more efficient strategies for connecting and visualizing mathematics, as well as assessing students' understanding (Wilson, Cooney and Stinson, 2005.). On the other hand, some of the recognized strategies aimed to enhance students' comprehensiveness in learning mathematics are use of varied approaches for engaging students in the learning process (precisely; ICT use, writing ideas, team-working, applying mathematics, hands-on and laboratory activities etc.) (Wilson, Cooney and Stinson, 2005.), encouraging hypothesis making plus building and defending student strategies of mathematical problem-solving (Lampert, 1991.) and discussing the limitations of students' current methods together with finding alternatives (Cobb, 1988.). However, the overarching precondition for the successful process of competence development is a students' perception of free, safe, errors-allowing learning environment in which they are inclined to actively participate. Alternatively, Voigt (1985.) points out that if teachers impose methods, i.e. outline them as demands, not suggestions, students are likely to run away from constructive learning activities into finding whichever shorter, superficial way that leads to demonstration of mathematical behavior teachers expect (Cobb, 1988.; Schoenfeld, 1988.), not resulting in profound understanding.

Evidently, in order to enhance the development of broadly considered mathematical competence, various constructivist-based teaching methods should be deliberately employed. However, if teaching strategies used in classrooms still largely fall under the scope of what is considered to be direct instruction (as it is evidenced by numerous studies across educational settings, e.g. Malzahn, 2002; Baranović, 2006), is it realistic to expect the development of broader, functional and 'realisitc' mathematical competence to be occurring and be apparent in the results of assessments?

As Halász and Michel report for the full spectrum of Key Competences, beyond the normative curricular definition of the goals of mathematical instruction lies the more difficult practical implementation resting on the change of professional behaviour of teachers who already have deeply rooted instruction and assessment practices. This requires classroom level innovations which still need to be implemented Europe-wide (Council of the European Union, 2010., as cited in Halász and Michel, 2011.:298). New ways of organising learning in an innovative school environment remains a task to be completed in an implementation of the mathematical competence framework. But Halász and Michel's analysis admits that changing learning environments is the most difficult implementation challenge. This poses system-level requirements for 'national educational innovation', but also massive investment in teacher 'capacity development' (Halász and Michel, 2011.:303-304) so that they become capable of adapting their classroom level practices to the educational goals defined in the novel way.

One of the things this improvement involves, in connection with the requirement to provide learning applicable in contexts outside classrooms, is the orientation on student-centred instruction. Depaepe, De Corte, and Verschaffel's (2007.) study particularly highlights that curricular and textbook innovation alone is insufficient to successfully implement the novel instruction approaches. Specifically, it is the teachers who play a very active role in the implementation of the curricular materials. They 
interpret, and this may be unconscious, the new instructions through their existing and prior knowledge and set practice patterns. Even more importantly, the demands of the aforementioned constructivist-based instruction may be too complex for the teachers who have been trained in the traditional delivery of mathematical concepts and standard examples for practice. Ensor (2001.) can be drawn on to highlight and illustrate the importance of in-service training to raise awareness of the obstacles expected based on the previous studies, as well as the specific preconceptions that a group of teachers situated in a particular national context may have.

There is research (Erickson, 1999.) showing that problem-based learning (PBL) strategies in classroom can assist with the added value of competence outcome, as opposed to bare knowledge and mathematical skills developed through traditional instruction. Applying mathematics to everyday life and complex interaction of knowledge from multitude of domains requires students to readily combine the mathematical conceptual knowledge with the problem solving and communication skills, creative and critical thinking skills, as well as positive attitude and values (Tamirzi et al., 2010.:4864). Innovative teaching methods, such as problem-based learning, have on their own not been shown to have a significant influence on conventional mathematical assessment performance compared to traditional teaching, but have made significant difference to the mental effort invested into the real-life mathematics problems (Tarmizi, Tarmizi, Lojinina, and Mokhtara, 2010.). Needless to say, problem based-learning is not the only instruction strategy to be applied in competence-oriented classroom, nor is all mathematics curricular content suitable for problem-based instruction.

Though this does not make them an ideal candidate for raising national PISA scores, it suggests that they can play a role in producing learning outcomes more suited to the competence-model. Other studies (Depaepe et al., 2007.; Silver and Stein, 1996.), performed in a longer run of lessons, suggest that there is a significant difference even in the test performance and post-test retention in favour of the problem-based instruction. Even more importantly, problem-based learning led to more positive beliefs about and attitudes towards learning and teaching mathematical problem solving, and even greater readiness to apply the problem-solving skills gained in real-life situations. These are all important factors in both students' motivation for adoption of mathematical content and the type of educational outcome that international assessments like PISA aim for.

Problem-based or investigative learning is a teaching method in which students are exposed to realistic, simulated real-life problems that are ill-structured and vague before they are exposed to new concepts and skills training covering the problem (Bridges and Hallinger, 1992.). Whilst a broader delineation of the scope and structure of problem-based learning is beyond the scope of this text (cf. Hmelo-Silver, 2004.), the given definition is useful for conceptual and instructional comparisons drawn on in this text. The popularity of the teaching method grew internationally (Savin-Baden and Major, 2004.; De Corte and Verschaffel, 2006.) over the last few decades, as it raises students motivation to learn because the outcome is no longer a successful completion of a school task ("for the sake of school", Tarmizi et 
al., 2010.:4864) but the real life problems whose solution is meaningful outside the school context. In that case the problem itself becomes the instrument of learning, and through successful solution of the problem learning is inevitable (Culver, 2000.; Kain, 2003.). This is opposed to the traditional mathematics instruction which is focused on exercise, rules, concepts and mathematical relations to be learnt, but which can easily turn out to be of limited use in unfamiliar real-life 'mathematical' situations. Unlike in the problem-based learning situations, traditional instruction does not provide much opportunity to develop one's own innate abilities and adapt and change the methods applied to a task so as to fit new situations. Because of its focus on group work and proving the successful solution of the problem, problembased learning fosters communication, graphical and visual presentation, modelling and explicit group-reasoning.

Following Tarmizi et al. (2010.) we will take problem-based learning to consist of the introduction of a real-life mathematics problem before being exposed to the mathematical concept that was named as part of the learning outcome of the lesson. Multiple paths to the problem solution are encouraged, and individual exploration takes place. The students take to solving the problem through the group discussion and the helpful notes from the teacher and examples from textbooks. This can also include students' own mathematical formulation of the problem (as opposed to its real-life description), predicting possible solutions, experimenting with different real-life situations and running their own student projects. Following the completion of the task the students present their solution as a group, and the teacher in the end summarises and reinforces the new concepts learnt.

The traditional teaching, on the other hand, is based on the teacher-centred instruction where students are led through introduction of new concepts and their use in mathematical problem examples. The students most often copy this demonstration from the blackboard. The students are then asked to practice similar questions as the ones shown in examples by the teacher. They will also eventually be examined on the questions similar to the ones practiced, through following tasks set in the workbook or exercise book. Some of the practice can be done by individual students on the blackboard, whilst others can follow and copy in their own notebooks. Part of student learning may also be to complete the lesson by demonstrating ability to publicly repeat definitions and formulas. The instruction itself is in this case seldom interactive and most of the communication is one-way, with students as recipients.

In Croatia, recent research on the teaching methods, teaching materials and tools shows (Baranović and Štibrić, 2011.) that the traditional approach to the mathematics teaching prevails in its many dimensions. ${ }^{9}$ According to the teachers' own responses, during mathematics lessons the Croatian students in compulsory edu-

9 We relate to the findings of the research described in the footnote 1. 
cation most often solve standard mathematical tasks. For instance, most teachers reported $^{10}$ that their students predominantly solve tasks they have demonstrated (93.5\% of responses), practice mathematical problems similar to those in the exam (87.3\% of responses), solve standard tasks individually at their desks (84.0\% of responses), work on formal tasks from workbooks or textbooks (82.0\% of responses). On the other hand, the teachers reported that their students are least engaged in independent exploration of mathematical concepts and patterns in the classroom (5.9\% of responses), application of mathematical concepts and patterns outside of the classroom (10.9\% of responses), explanation of their ideas and reasoning about mathematics topics in written form (13.1\% of responses), performing their own student projects (14.0\% of responses), articulation of their own mathematical problems (14.8\% of responses), etc.

The use of teaching methods reflects this traditional approach as the teachers most often use traditional teaching materials and tools while they rarely use contemporary ICT and visualisation tools. More than $90 \%$ of teachers stated that they use geometric demonstration equipment (97\%) and students' textbooks (91\%) often and very often. A great number of them also use printed task-sheets and workbooks (90\%) and so called 'mathematical manipulatives' (84\%). But only one third of the teachers use the Internet, one fifth use mathematics software (e.g. Geogebra, Geometar-Skechpad) and $16 \%$ of teachers use the mass media (e.g. newspaper, TV) as sources or aides.

With, for example investigative or problem-based, learning's connection to the everyday application of mathematical knowledge and post-test retention of knowledge, Croatia's predominantly traditional teaching methods and tools seem out of sync with requirements for development of mathematical competence. Despite teachers' appropriation of the novel goals of application of mathematics to everyday life, their teaching methods still reflect the deeper attachment to the traditional aim of the transmission of abstract mathematical knowledge. On the other hand, traditional instruction and focus on 'practice-makes-perfect' drilling instruction does not on its own lead to increase in performance at international standardized testing for a broad spectrum of students. Given the shift to competence-oriented aims of mathematics instruction, a more arduous task of changing teaching practices remains (Halász and Michel, 2011. above). As Julie (2006.) warns, mathematical literacy is more difficult to teach than standard school mathematics.

In conclusion, having shown that traditionally framed concept of mathematics was dominant in mathematics curricula and teachers' perception until very recently, as well as the prevalence of traditional components in the mathematics instruction in

10 For the purpose of measuring the frequency of the students' activities during the mathematics lessons a scale consisting of 21 items (students activities) was developed. The items were set on 5-grade Likert scale with possible answers "never" (1), very rarely (2), sometimes (3), often (4) and "very often" (5). The percentages of teachers' responses: „often" and „very often" are presented in the text. 
compulsory education in Croatia, we conclude that enacted/implemented mathematics curricula should be substantially changed if we want to improve mathematical literacy or competence of Croatian students. In line with the international trends and recent Croatian curricular changes it is laudable that teachers have largely adopted the view of mathematics as applicable to students' everyday life and potential for lifelong learning, but this remains to be developed through curricular concepts to operational level.

Beyond the laudable aims, most teachers still see set-task completion and concept adoption as the main forms of mathematical learning. Against the recent trends for, and early calls in 1991. curricular description of mathematics, Croatian teachers still largely employ teacher-centred traditional instructional methods. Though these can lead to high testing scores, as exemplified by the East Asian economies, on their own they are insufficient to lead to the broader competence-framed outcomes of learning. With PISA results unimpressive and the perceived difficulty of school mathematics, changes to pre-service education and in-service teacher training are recommended, so as to include detailed understanding of the new aims of mathematics instruction and the methods of achieving those.

\section{References}

1. Baranović, B. (2006). Nastavni programi iz perspektive nastavnika i učitelja [The teaching programmes from the perspective of teachers], in: B. Baranović (Ed.). Nacionalni kurikulum za obavezno obrazovanje u Hrvatskoj: različite perspektive. Zagreb: Institut za društvena istraživanja.

2. Baranović, B., and Štibrić, M. (2011, 13-16 September). Implementation of math curriculum as part of the core curriculum in Croatia. Paper presented at European Conference on Educational Research - Urban Education, Berlin.

3. Bishop, A. J.; Clements, K.; Keitel, C.; Kilpatrick, J.; La-borde, C. (Eds.). (1996). International handbook of mathematics education. Dordecht: Kluwer Academic Publishers.

4. Bridges, E. and Hallinger, P. (1992). Problem-based learning for administrators. Eugene, OR: ERIC Clearinghouse on Educational Management.

5. Cobb, P. (1988). The Tension between Theories of Learning and Instruction in Mathematics Education. Educational Psychologist, 23 (2): 87-103.

6. Culver, J. A. (2000). Effectiveness of problem-based learning curricula: Research and theory. Academic Medicine, 75: 259-266.

7. De Corte, E. and Verschaffel, L. (2006). Mathematical thinking and learning, in: W. Damon, R. Lerner, I. Sigel, A. Renninger (Eds.). Handbook of child psychology. Vol 4: Child psychology and practice (6th ed.). Hoboken. NJ: Wiley.

8. Depaepe, F.; De Corte, E. and Verschaffel, L. (2007). Unraveling the culture of the mathematics classroom: A video-based study in sixth grade. International Journal of Educational Research, 46: 266-279.

9. Domazet, M. (2006). Hard knowledge, soft values. Sociologija sela, 44: 505-524. 
10. Domazet, M. (2011). Poučimo ih da odlučuju: važnost građanskog („državljanskog“) odgoja u sklopu razvoja prirodoznanstvene kompetentnosti hrvatskih učenika, u: Afrić, V.; Bakić-Tomić, Lj.; Polšek, D.; Žažar, K. (Ur.). Društvene pretpostavke društva znanja. Zagreb: FF Press, Institut Pilar, Akademija pedagoških znanosti.

11. Engeström, Y. (1993). Developmental studies of work as a testbench of activity theory: The case of primary care medical practice, in: S. Chaiklin and J. Lave (Eds.). Understanding practice: Perspectives on activity and context. Cambridge: Cambridge University Press.

12. Ensor, P. (2001). From preservice mathematics teacher education to beginning teaching: A study in recontextualizing. Journal for Research in Mathematics Education, 32: 296-320.

13. Erickson, D. K. (1999). A problem-based approach to mathematics instruction. Mathematics Teacher, 92: 516-521.

14. Freundethal, H. (1973) Mathematics As An Educational Task. Dordrecht: D. Reidel Publishing Company.

15. Furlan, I.; Kaučić, B.; Muhvić, Z.; Podgorski, I.; Zadrović, A. (Eds.). (1974). Naša osnouna škola (Our Primary School). Zagreb: Školska knjiga.

16. Glasnović Gracin, D. (2012, May). Mathematische Anforderungen in Schulbüchern und in der PISA Studie. Paper presented at the Jahrestagung der Gesellschaft für Didaktik der Mathematik, Weingarten. Retreived from (http://www.mathematik. uni-dortmund.de/ieem/bzmu2012/files/BzMU12 0100 Glasnovic Gracin.pdf).

17. Greeno, J. G. (2006). Learning in activity, in: R. K. Sawyer (Ed.). The Cambridge handbook of the learning sciences. Cambridge: Cambridge University Press.

18. Gresalfi, M.; Martin, T.; Hand, V.; Greeno, J. (2009). Constructing competence: An analysis of student participation in the activity systems of mathematics classrooms. Educational Studies in Mathematics, 70: 49-70. doi 10.1007/s10649-0089141-5.

19. Halász, G. and Michel, A. (2011). Key competences in Europe: Interpretation, policy formulation and implementation. European Journal of Education, 46: 289-236.

20. Heuvel-Panhuizen, M. Van Den (2003). The Didactical Use of Models in Realistic Mathematics Education: An Example from a Longitudinal Trajectory on Percentage. Educational Studies in Mathematics, 54: 9-35.

21. Hmelo-Silver, C. E. (2004). Problem-Based Learning: What and How Do Students Learn?. Educational Psychology Review, 16 (3): 235-266.

22. Hoogland, K. and Jablonka, E. (2003). Wiskundige geletterdheid en gecijferdheid [Mathematical literacy and numeracy]. Nieuwe Wiskrant. Tijdschrift voor Nederlands Wiskundeonderwijs, 23 (1): 31-37. English translation (pp. 1-7) retrieved from (http://www.gecijferdheid.nl/Publicaties/HooglandJablonka_UK.PDF).

23. Jablonka, E. (2003). Mathematical literacy, in: A.J. Bishop; M.A. Clements; C. Keitel; J. Kilpatrick; F.K.S. Leung (Eds.). Second International Handbook of Mathematics Education. Dordecht: Kluwer Academic Publishers.

24. Jakopović, S. (Ed.). (1991). Nastavni plan i program za osnovne škole u Republici Hrvatskoj (izmjene $i$ dopune) [Teaching plan and programme for primary schools in the Republic of Croatia]. Zagreb: Zavod za školstvo Ministarstva prosvjete i kulture Republike Hrvatske. 
25. Julie, C. (2006). Mathematical literacy: Myths, further inclusions and exclusions. Pythagoras, 64: 62-69.

26. Kain, D. L. (2003). Problem-based learning for teachers, grades K-8. Boston: Allyn and Bacon.

27. Kazemi, E. and Stipek, D. (2001). Promoting conceptual thinking in four upperelementary mathematics classrooms. Elementary School Journal, 101: 59-80.

28. Keitel, C. and Kilpatrick, J. (1999). The Rationality and Irrationality of International Comparative Studies, in: G. Kaiser; E. Luna and I. Huntley (Eds.). International Comparisons in Mathematics Education. London: Falmer Press.

29. Lampert, M. (1991). Connecting mathematical teaching and learning, in: E. Fennema; T. P. Carpenter and S. J. Lamon (Eds.). Integrating research on teaching and learning mathematics. Albany, NY: SUNY.

30. Lapointe, A. E.; Mead, N. A. and Askew, J. M. (Eds.). (1992). The international assessment of educational progress report No. 22-CAEP-01: Learning mathematics. New Jersey: Educational Testing Service.

31. Lemke, J. L. (1990). Talking science. Norwood, NJ: Ablex.

32. Leung, F. and Park, K. (2002). Competent students, competent teachers?. International Journal of Educational Research, 37: 113-129.

33. Ma, L. (1999). Knowing and teaching elementary mathematics. Mahwah, NJ: Lawrence Erlbaum Associates.

34. Malzahn, K. A. (2002). Status of Elementary School Mathematics Teaching. 2000 National Survey of Science and Mathematics Education. Horizon Research, Inc.

35. Marušić, I. (2006). Nastavni programi iz perspektive učenika [The teaching programmes from the students' perspective], in: B. Baranović (Ed.). Nacionalni kurikulum za obavezno obrazovanje u Hrvatskoj: različite perspektive. Zagreb: Institut za društvena istraživanja.

36. Mešić, V. (2012). Identifying Country-Specific Cultures of Physics Education: A differential item functioning approach. International Journal of Science Education 34 (16): 2483-2500

37. Ministry of Education and Sport of Republic of Croatia. (1999). Nastavni plan i program za osnovnu školu [Teaching plan and programmes for elementary schools] [Special Issue]. Prosvjetni vjesnik, 2.

38. Ministry of Science, Education, and Sports of Republic of Croatia. (2006). Croatian national educational standards (CNES). Zagreb: Author. Retrieved from (http://public.mzos.hr).

39. Ministry of Science, Education and Sports of Republic of Croatia (2011). National curriculum framework for pre-school education and general compulsory education and secondary education. Zagreb: Author. Retrieved from (http:// public.mzos.hr/Default.aspx?sec=2497).

40. Niss, M. A. (2003). Mathematical competencies and the learning of mathematics: The Danish KOM project, in: Gagatsis, A. and Papastavridis, S. (Eds.). 3rd Mediterranean Conference on Mathematical Education - Athens, Hellas 3-4-5 January 2003. Athens: Hellenic Mathematical Society.

41. Niss, M. A. (2003). Quantitative literacy and mathematical competencies, in: Madison, B. and Steen, L. (Eds.). Quantitative literacy: Why numeracy matters for schools and colleges. Princeton: National Council on Education and the Disciplines. 
42. Office for Official Publications of the European Communities (CEDEFOP) (2008). Terminology of European education and training policy - A selection of $100 \mathrm{key}$ terms. Luxembourg: Author.

43. Organisation for Economic Co-operation and Development (1999). Measuring student knowledge and skills: A new framework for assessment. Paris: Author.

44. Organisation for Economic Co-operation and Development (2003). The PISA 2003 assessment framework - Mathematics, reading, science and problem solving knowledge and skills. Paris: Author.

45. Organisation for Economic Co-operation and Development (2009). The PISA 2009 assessment framework. Paris: Author.

46. Organisation for Economic Co-operation and Development (2010). PISA 2009 results: What students know and can do - Student performance in reading, mathematics and science (Volume I). Retrieved from (http://dx.doi. org/10.1787/9789264091450-en).

47. Rychen, D. S. and Salganik, L. H. (2003). A holistic model of competence, in: D. S. Rychen and L. H. Salganik (Eds.). Key competencies for a successful life and well-functioning society. N.p.: Hogrefe and Huber.

48. Savin-Baden, M. and Major, C. H. (2004). Foundations of problem-based learning. Berkshire, England: Society for Research into Higher Education and Open University Press.

49. Schmidt, W. H.; Wang, H. C. and MCKnight, C. C. (2005). Curriculum coherence: an examination of US mathematics and science content standards from an international perspective. Journal of Curriculum Studies, 37 (5): 525-559.

50. Schoenfeld, A. H. (1988). When Good Teaching Leads to Bad Results: The Disasters of „Well-Taught“ Mathematics Courses. Educational Psychologist, 23 (2), 145-166.

51. Schoenfeld, A. H. (2002). Making Mathematics Work For All Children: Issues Of Standards, Testing, And Equity. Educational Researcher, 31(1): 13-25.

52. Silver, E. A. (2003, 5-8 March). Conceptions of mathematical competence. Paper presented at the DFG-NSF International Conference on Research and Development in Mathematics and Science Education, Kiel, Germany.

53. Silver, E. A. and Stein, M. K. (1996). The Quasar project: The "revolution of the possible" in mathematics instructional reform in urban middle schools. Urban Education, 30: 476-521.

54. Sriraman, B. and English, L. (Eds.). (2010). Theories of Mathematics Education. Berlin, Heidelberg: Springer-Verlag.

55. Stevenson, H. W.; Lummis, M.; Lee, S.; Stigler, J. (1990). Making the grade in mathematics: Chinese, Japanese and American children. Reston, VA: National Council of Teachers of Mathematics.

56. Tarmizi, R. A.; Tarmizi, M. A. A.; Lojinina, N. I.; Mokhtara, M. Z. (2010). Problembased learning: Engaging students in acquisition of mathematical competency. Procedia - Social and Behavioral Sciences, 2: 4683-4688.

57. Turner, J. C.; Meyer, D. K.; Cox, K. E.; Logan, C.; DiCintio, M.; Thomas, C. (1998). Creating contexts for involvement in mathematics. Journal of Educational Psychology, 90: 730-745.

58. Voigt, J. (1985). Patterns and routines in classroom interaction. Recherches en Didactique des Mathematiques, 6: 69-118. 
59. Wilson, P. S.; Cooney, Th. J. and Stinson, D. W. (2005). What Constitutes Good Mathematics Teaching And How It Develops: Nine High School Teachers' Perspectives. Journal of Mathematics Teacher Education 8: 83-111. 
Pregledni rad

\section{Mladen Domazet}

Institut za društvena istraživanja u Zagrebu (Centar za istraživanje i razvoj obrazovanja), Hrvatska e-mail:domazet@idi.hr

Branislava Baranović

Institut za društvena istraživanja u Zagrebu (Centar za istraživanje i razvoj obrazovanja), Hrvatska e-mail: baranov@idi.hr

Jelena Matić

Institut za društvena istraživanja u Zagrebu (Centar za istraživanje i razvoj obrazovanja), Hrvatska

e-mail:matic@idi.hr

\section{Matematička kompetencija i međunarodna testiranja matematike: hrvatsko polazište}

\section{Sažetak}

Članak donosi pregled koncipiranja obveznog matematičkog obrazovanja kroz kompetencijske ishode te prikladnih metoda poučavanja. Takav pregled daje se u svjetlu međunarodnih utjecaja na koncipiranje matematičkog obrazovanja u Hrvatskoj kroz rangiranje matematičke pismenosti 15-godišnjaka u PISA testiranju. Na početku se obrazlažu konceptualni konstrukti u pozadini društvenih utjecaja na nad-državni razvoj pojma pismenosti/kompetentnosti u obrazovanju i testiranju iz matematike. U tom svjetlu pregledavaju se prošla i sadašnja, te predlažu moguća buduća, određenja i promjene školskog matematičkog obrazovanja i procesa poučavanja matematike u hrvatskim osnovnim školama. Pregled empirijskih istraživanja praksi i stavova o matematičkom obrazovanju u posljednjih nekoliko godina komplement je pregledu teoretskih određenja. Cilj je istražiti i prikazati društvene i (komparativne) političke utjecaje na sadržaj i poučavanje ‘čvrstih' školskih predmeta kao što je matematika, obilježiti trenutnu hrvatsku poziciju po međunarodnim testiranjima i empirijskim istraživanjima stavova učenika i nastavnika, te preporučiti moguće neposredne korake u razvoju obrazovne politike u području matematičkog obrazovanja.

Ključne riječi: PISA testiranje, kompetencije, pismenost, matematika, poučavanje, učenje kroz rješavanje problema, obvezno obrazovanje u Hrvatskoj. 